\title{
Use of Non-conventional Chemicals against Stem Rot of Groundnut (Arachis hypogaea L.) Caused by Sclerotium rolfsii Sacc.
}

\author{
Durga Prasad Awasthi ${ }^{1}$, Narendra Kumar Mishra ${ }^{2 *}$ and Basudev Dasgupta ${ }^{3}$
}

${ }^{1}$ College of Agriculture, Tripura, Lembucherra, Tripura West, India-799 001

${ }^{2}$ College of Agriculture and Research Station, Korea, Chhattisgarh, India - 497335

${ }^{3}$ Department of Plant Pathology, Bidhan Chandra Krishi Viswavidyalaya, Mohanpur, Nadia, West Bengal, India-741 252

*Corresponding

\section{A B S T R A C T}

\section{Keywords}

Indole acetic acid, Molar

concentration,

Disease incidence,

Disease severity

and yield

Article Info

Accepted:

15 January 2018

Available Online:

10 February 2018
Stem rot of groundnut (Arachis hypogaea L.) caused by Sclerotium rolfsii Sacc. is a serious fungal disease of groundnut. Conventional uses of fungicides are toxic to environment thus an eco-friendly new approach of management with nonconventional chemicals as seed treatment was undertaken. Seeds of groundnut were soaked in non-conventional chemicals namely, $\mathrm{ZnSO}_{4}, \mathrm{ZnCl}_{2}, \mathrm{BaSO}_{4}, \mathrm{BaCl}_{2}$, Cycocel and Indole Acetic Acid (I.A.A) @ $10^{-4}$ and $10^{-5}$ Molar concentrations for 24 hours to evaluate its bio-efficacy against the disease. The results of the present study revealed that lowest disease incidence $(25.7 \%)$, lowest disease severity $(21.7 \%)$ as well as highest significant yield $\left(486.8 \mathrm{~g} / \mathrm{m}^{2}\right)$ was recorded when seeds are soaked in solution of IAA at $10^{-5} \mathrm{M}$ concentration for 24 hours.

\section{Introduction}

Groundnut (Arachis hypogaea L.) is one of the principle economic oilseed crops of the world. It belongs to family leguminoseae based on its growth habit, taste, color, size, characters of pods, leaf character etc. Due to year round cultivation, groundnut crop is subjected to suffer from a number of diseases caused by fungi, bacteria, virus, mycoplasma like organism, nematodes etc. Out of different diseases, stem rot of groundnut caused by
Sclerotium rolfsii Sacc. is a very important disease causing severe yield losses. In the first half of $20^{\text {th }}$ Century, peanut production sustained losses of 10 to 20 million US dollars annually due to this disease. Losses of 25 to $50 \%$ were recorded in 1938-1947. In India, this pathogen causes appreciable losses in chilli, bean, beet, carrot, cucurbit, potato, spinach betel-vine and peanut also (Aycock, 1966). Sclerotium rolfsii Sacc. Teleomorph: Athelia rolfsii (Curzi) Tu and Kimbrough is a destructive fungal plant pathogen causing 
diseases in many mono and dicotyledonous plants encompassing more than 500 host species (Punja, 1984). Despite continuous research over the past one century since its first report, management of the pathogen has remained a challenge. Control efforts have often met with limited success, partially due to the extensive host range, prolific growth rate and ability of the pathogen to produce large number of sclerotia that may remain viable in soil for several years. Furthermore, control measures effective for a particular crop in an area may not be adaptable elsewhere due to regulatory or economic constraints. Spray of chemical fungicides possesses a serious threat to beneficial organisms of ecosystem. Thus, the present study was undertaken with the objective to induce resistance in host against the pathogen by treating the seeds with non-conventional chemicals.

\section{Materials and Methods}

The experiment was conducted at Kalyani, District Nadia, and West Bengal, India. The experimental was carried out in a Randomized Block Design having 11 treatments and 3 replications with 6 nonconventional chemicals for two consecutive years in order to find out their effectiveness in reducing disease incidence, severity and increasing yield using groundnut variety JL24. The six non conventional chemicals comprised 4 different metal salts of diverse nature and two plant growth hormones at a concentration of $10^{-4}$ and $10^{-5} \mathrm{M}$ for each chemical used. The chemicals were namely, Barium Chloride $\left(\mathrm{BaCl}_{2}\right)$, Barium Sulphate $\left(\mathrm{BaSO}_{4}\right)$, Zinc Chloride $\left(\mathrm{ZnCl}_{2}\right)$, Zinc Sulphate $\left(\mathrm{ZnSO}_{4}\right)$, Cycocel and Indole Acetic Acid (IAA).

One molar solution (M) was prepared by taking the amount $(\mathrm{g})$ of molecular weight of each chemical dissolved in one liter of water.
From that solution $(1 \mathrm{M})$ of each chemical $10^{-4}$ $\mathrm{M}$ and $10^{-5} \mathrm{M}$ solutions of each chemical were used for soaking of seed materials. Before sowing, the seeds were surface sterilized with $0.1 \%$ sodium hypochlorite solution for 2 minutes and thoroughly rinsed in running tap water for 5 times and then rinsed in sterile water. These seeds were then soaked for 24 hours in respective salt solutions.

The treated seeds were air-dried keeping in room temperature and then sown in the field. Control (without chemical) was also maintained by soaking the seeds in sterile water only. In all cases three replications were maintained along with control. The Percent disease incidence and percent disease index was recorded at 60 DAS and 90 DAS respectively. The assessment of disease severity was done on $0-4$ scale as follows:

$0=$ Healthy plants, $1=$ Yellowing, $2=$ Browning and white mycelial growth near the basal part of stem, $3=$ Wilting, $4=$ Complete collapse of the plant.

\section{Results and Discussion}

The results of the present trial revealed that all the chemicals namely, $\mathrm{BaCl}_{2}, \mathrm{BaSO}_{4}$, $\mathrm{ZnCl}_{2}, \mathrm{ZnSO}_{4}$, Indole Acetic Acid and Cycocel at $10^{-5}$ and $10^{-4}$ Molar concentration significantly controls stem rot of groundnut than control plots.

\section{Per cent disease incidence}

Lowest disease incidence was recorded in the treatment IAA $10^{-5} \mathrm{M}(25.7 \%)$ whereas, highest disease incidence was recorded in control treatment and it was statistically significant to all other treatment (Table 1). Maximum per cent disease over control was recorded in IAA $10^{-5} \mathrm{M}$ concentrations (55.72 $\%)$. 


\section{Per cent disease index/severity}

Lowest disease severity was recorded in the treatment IAA $10^{-5} \mathrm{M}(21.7 \%)$ and it was statistically significant to all other treatment (Table 1). Highest disease severity was recorded in control treatment and which was also statistically significant. The per cent disease severity over control of the pooled data showed that maximum per cent disease severity over control was recorded in IAA $10^{-5} \mathrm{M}$ concentration (59.1\%).

\section{Effect on yield}

Pooled analysis (Fig. 1) of two years data revealed that the highest yield was obtained in IAA $10^{-4} \mathrm{M}\left(499.7 \mathrm{~g} / \mathrm{m}^{2}\right)$ and it was statistically at par with IAA $10^{-5} \mathrm{M}(486.8$ $\mathrm{g} / \mathrm{m}^{2}$ ) followed by $\mathrm{BaSO}_{4} 10^{-4} \mathrm{M}$ (476.0 $\mathrm{g} / \mathrm{m}^{2}$ ). Yield of other treatments were also found to be significant when compared with control or untreated plots. Various workers have reported phenomenon of induced resistance using non-conventional chemicals against various pathogens including S. rolfsii. Bag and Singh (1997) reported the use of non-conventional chemicals in control of stem rot of soybean. They found that barium sulphate, lithium sulphate, manganese sulphate, cupric chloride, ferric chloride substantially (61-77\%) able to inhibit disease symptoms and reduced plant mortality by 45 to $75 \%$ in comparison to control. Similarly, Dasgupta et al., (2000) reported the effectiveness of mercuric chloride, barium sulphate, ferric chloride, barium nitrate and zinc chloride in control of collar rot disease of groundnut caused by Aspergillus niger up to 50 to $66.5 \%$ reduction in disease incidence.

Table.1 Effect of non- conventional chemicals on stem rot of groundnut in terms of percent disease incidence

\begin{tabular}{|c|c|c|c|c|}
\hline \multirow[t]{2}{*}{ Treatment } & \multicolumn{2}{|c|}{$\begin{array}{l}\text { Per cent Disease Incidence at } \\
90 \text { DAS }\end{array}$} & \multicolumn{2}{|c|}{$\begin{array}{c}\text { Per cent Disease Severity at } 90 \\
\text { DAS }\end{array}$} \\
\hline & $\begin{array}{l}\text { Pooled } \\
(\%)\end{array}$ & $\begin{array}{l}\text { Percent disease } \\
\text { control (\%) }\end{array}$ & Pooled (\%) & $\begin{array}{l}\text { Percent disease } \\
\text { control }(\%)\end{array}$ \\
\hline $\mathrm{ZnSO}_{4}\left(10^{-4}\right)$ & 37.3 & 35.7 & 32.6 & 38.6 \\
\hline $\mathrm{ZnSO}_{4}\left(10^{-5}\right)$ & 35.9 & 38.15 & 30.1 & 43.3 \\
\hline Cycocel $\left(10^{-4}\right)$ & 40.3 & 30.57 & 33.0 & 37.9 \\
\hline Cycocel $\left(10^{-5}\right)$ & 43.5 & 25.06 & 39.75 & 25.2 \\
\hline $\mathrm{ZnCl}_{2}\left(10^{-4}\right)$ & 40.38 & 30.43 & 40.05 & 24.6 \\
\hline $\mathrm{ZnCl}_{2}\left(10^{-5}\right)$ & 34.8 & 40.05 & 33.65 & 36.6 \\
\hline IAA $\left(10^{-4}\right)$ & 30.78 & 46.97 & 32.6 & 38.6 \\
\hline IAA $\left(10^{-5}\right)$ & 25.7 & 55.72 & 21.7 & 59.1 \\
\hline $\mathrm{BaSO}_{4}\left(10^{-4}\right)$ & 26.2 & 54.86 & 24.6 & 53.7 \\
\hline $\mathrm{BaSO}_{4}\left(10^{-5}\right)$ & 29.8 & 48.66 & 25.6 & 51.8 \\
\hline $\mathrm{BaCl}_{2}\left(10^{-4}\right)$ & 32.38 & 44.22 & 27.3 & 48.6 \\
\hline $\mathrm{BaCl}_{2}\left(10^{-5}\right)$ & 34.78 & 40.08 & 30.65 & 42.3 \\
\hline Control & 58.05 & 0.0 & 53.15 & 0.0 \\
\hline SEd & 0.587 & - & 0.598 & - \\
\hline CD at (0.05) & 1.211 & - & 1.20 & - \\
\hline
\end{tabular}


Figure.1 Effect of non- conventional chemicals on yield of stem rot of groundnut

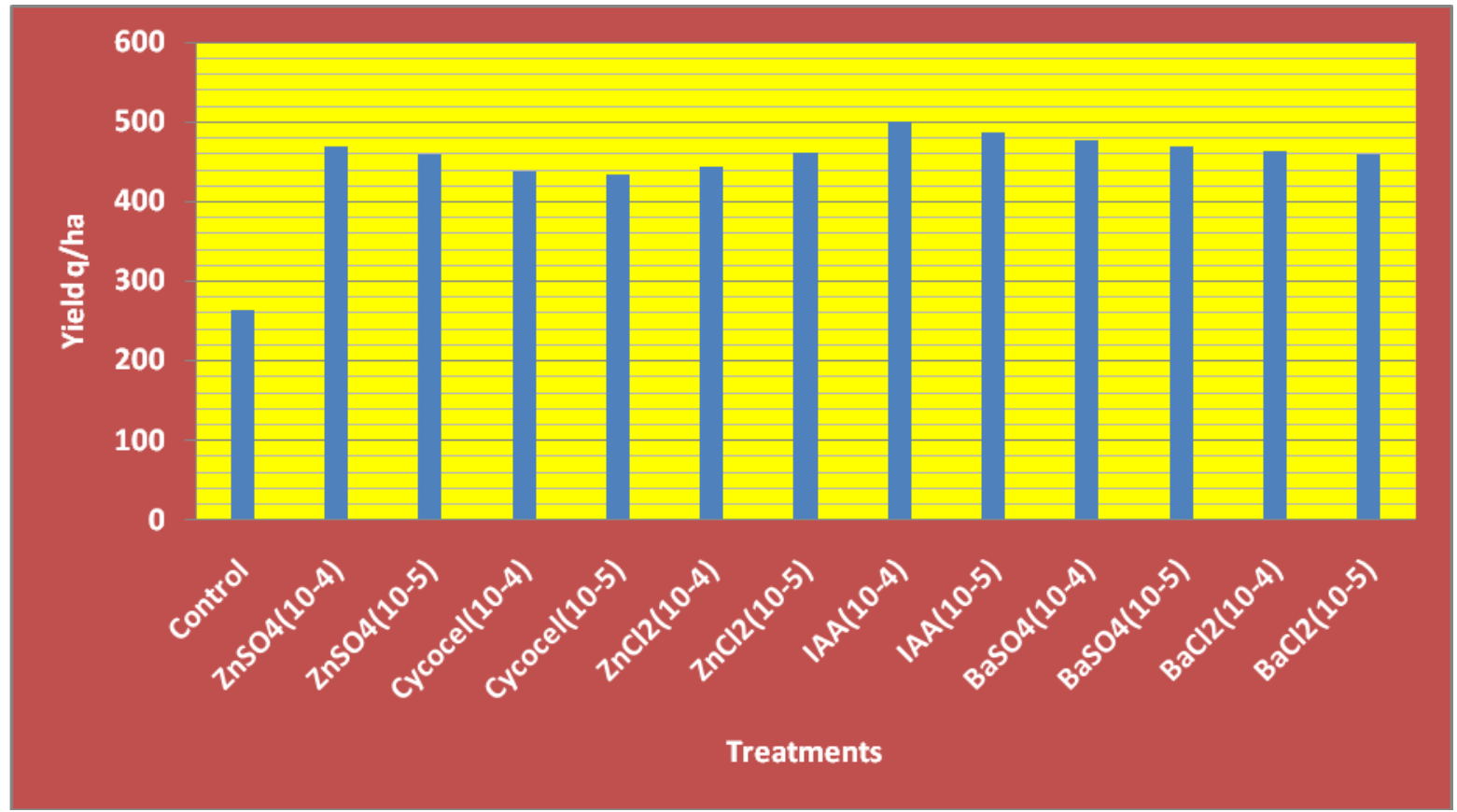

Ganguly (1996) recorded good protection of sheath blight of rice by using nonconventional chemicals like ferric chloride, cadmium chloride, zinc chloride and cupric chloride. Seed treatment with nonconventional chemicals induces considerable resistance in groundnut plant against $S$. rolfsii. The inhibitory effect was most striking in reducing disease incidence and plant mortality. According to Mitra and Chowdhury (2001) as well as Bateman (1964) stated that plant tissues treated with non conventional chemicals had marked reductions in specific polygalacturonase activity compared to untreated plants. Calcium and magnesium levels of treated plants also increased as compared to untreated one. Accumulation of calcium and magnesium leads to transformation of enzyme-sensitive cell wall pectic components and around the lesion site to less soluble enzyme tolerant $\mathrm{Ca}$ and $\mathrm{Mg}$ pectate and this act as a dynamic resistance factor. Reduction in oxalic acid content in the treatments might be another reason by which non-conventional chemicals induces resistances (Faboya et al., 1983). Effective compounds appear to condition a susceptible plant through activation of its latent defense potential by sensitization of its tissue, so that it become a competent and ready to interact with the challenger pathogen as like the resistant plant behaves through their natural defense response. Thus, from the present case of study and above discussion we can conclude that soaking of seeds with nonconventional chemicals namely $\mathrm{ZnSO}_{4}$, $\mathrm{ZnCl}_{2}, \mathrm{BaSO}_{4}, \mathrm{BaCl}_{2}$ and I.A.A. @ $10^{-4}$ and $10^{-5} \mathrm{M}$ concentration were effective against stem rot of groundnut compared to untreated plots however, lowest disease incidence (25.7 $\%)$ and disease severity $(21.7 \%)$ was recorded when seeds are soaked in solution of IAA at $10^{-5} \mathrm{M}$ concentration for 24 hours.

\section{References}

Aycock R. 1966. Stem rot and other diseases caused by Sclerotium rolfsii. NC. Agric Exp Stn Tech Bull 174: 202.

Bag T.K. and Sinha A.K. 1997. Control of 
stem rot of soybean incited by Sclerotium rolfsii through metal salts. Indian Phytopath 50 (3): 350-357.

Bateman D.F. 1964. An induced mechanism of tissue resistance to polygalacturonase in Rhizoctonia infected hypocotyls of beans. Phytopathol 54: 438-445.

Dasgupta S., Raj S. K. and Das S. 2000. Control of collar rot disease of groundnut caused by Aspergillus niger by seed soaking with non-conventional chemicals. Indian Phytopathol 53 (2): 227-229.

Faboya O., Ikotum T. and Fatoki O.S. 1983. Production of oxalic acid by some fungi in infected tuber. Zallg Microbio 24: 621-624.
Ganguly L.K. 1996. A non conventional approach for chemical control of sheath blight of rice. Ph. D Thesis, Bidhan Chandra Krishi Visawavidyalaya, Mohanpur, West Bengal, India.

Mitra P. and Chowdhury A.P. 2001. Protection of soyabean seedling from Sclerotium rot by seed treatment with alternative chemical agents. $J$ Mycopathol Res 39 (1): 35-38.

Punja Z.K. and Jenkins S.F. 1984. Light and scanning electron microscopic observation of calcium oxalate crystals produced during growth of Sclerotium rolfsii in culture and in infected tissue. Can J Bot 62: 2028-32.

\section{How to cite this article:}

Durga Prasad Awasthi, Narendra Kumar Mishra and Basudev Dasgupta. 2018. Use of Nonconventional Chemicals against Stem Rot of Groundnut (Arachis hypogaea L.) Caused by Sclerotium rolfsii Sacc. Int.J.Curr.Microbiol.App.Sci. 7(02): 1288-1292.

doi: https://doi.org/10.20546/ijcmas.2018.702.157 